\title{
Declivity in steelhead (Oncorhynchus mykiss) recruitment at the Keogh River over the past decade
}

\author{
Bruce R. Ward
}

\begin{abstract}
Survival and return of unharvested winter-run steelhead (Oncorhynchus mykiss) at the Keogh River, British Columbia, declined abruptly and remained persistently low after 1990. Adult returns averaged 1168 fish from 1976 to 1990 but were significantly lower from 1991 to 1998 (mean 223). Forty wild females returned to the 35-km river in 1995-1996, 20 in 1996-1997, and <10 in 1997-1998. The positive linear relationship between smolts and returns was significantly lower after 1990 and no longer correlated with smolt size. Smolt-to-adult survival averaged $15 \%$ (1976 to 1989 ) but recently averaged $3.5 \%$ (1990 to 1995). Smolt number steadily declined to <1000 by 1998 from an average annual count of 7000. Smolts per spawner from 1991 to 1994 were, on average, $70 \%$ lower than previous estimates based on the same spawner abundance. Recruitment scenarios based on survival histories during freshwater and marine life stages indicated that adult recruits are currently below replacement and unsustainable if conditions continue or worsen. Factors influencing steelhead in the ocean and freshwater are likely similar for other salmonids; harvest impacts must be reduced and appropriate stock rebuilding measures implemented.
\end{abstract}

\begin{abstract}
Résumé : La survie et les échappées de truites arc-en-ciel anadromes (Oncorhynchus mykiss) de la remontée d'hiver de la rivière Keogh (Colombie-Britannique) ont chuté de façon abrupte et sont demeurées faibles après 1990. En moyenne, les remontées d'adultes se sont élevées à 1168 poissons de 1976 à 1990 pour ensuite décliner de façon appréciable de 1991 à 1998 (moyenne de 223). Quarante femelles sauvages sont revenues dans la rivière de 35 km en 1995-1996, 20 en 1996-1997 et <10 en 1997-1998. La relation linéaire positive entre le nombre de saumoneaux et les remontées était significativement plus faible après 1990, et la corrélation avec la taille des saumoneaux était disparue. Le taux de survie de saumoneaux à adultes qui était en moyenne de 15\% (1976 à 1989) a récemment diminué à 3,5\% (1990 à 1995). Le nombre de saumoneaux, dont la moyenne annuelle était de 7 000, a diminué de façon constante pour tomber à <1 000 en 1998. Le nombre de saumoneaux par géniteur au cours de la période de 1991 à 1994 était, en moyenne, de $70 \%$ inférieur aux valeurs antérieurement estimées pour une même abondance de géniteurs. Des scénarios de recrutement fondés sur l'historique de la survie pendant les étapes en eau douce et en mer ont montré que le recrutement des adultes était actuellement inférieur aux besoins du remplacement et que le caractère durable du stock ne pourrait être maintenu si les conditions continuaient à se détériorer. Les facteurs influant sur la truite arc-en-ciel anadrome tant en mer qu'en eau douce sont sans doute semblables à ceux affectant les autres salmonidés et il faudra réduire les incidences de la récolte et prendre des mesures appropriées pour le rétablissement des stocks.
\end{abstract}

[Traduit par la Rédaction]

\section{Introduction}

Wild steelhead (Oncorhynchus mykiss) in southern British Columbia have markedly and persistently declined in number over the last decade. In fisheries for both coho salmon (Oncorhynchus kisutch) and steelhead, the respective federal and provincial management agencies have seriously curtailed harvest, particularly in the Georgia Basin and the east coast of Vancouver Island, B.C. Zero fishing mortality, more selective fishing methods, and recovery plans have been recently announced in conservation-based management of coho salmon. Steelhead sport fisheries in southern British Columbia have been regulated by catch and release fishing since

Received January 9, 1999. Accepted July 16, 1999.

J14967

B.R. Ward. British Columbia Ministry of Fisheries, Fisheries Centre, 2204 Main Mall, University of British Columbia,

Vancouver, BC V6T 1Z4, Canada.

e-mail: Bruce.Ward@gems8.gov.bc.ca
1980, yet the number of adults encountered in sport fisheries, snorkel surveys, and other indices or trends in abundance continue downward (Smith et al. 2000).

Keogh River steelhead, winter-run (December to May) fish that are not subject to mortality from commercial interception or sport harvest, have been important as an indicator of stock status for British Columbia and towards the understanding of steelhead recruitment mechanisms. Past studies at the Keogh River have supported fisheries management and watershed rehabilitation efforts (Ward and Wightman 1989; Ward and Slaney 1990; McCubbing and Ward 1997). This and other earlier work from 1976 to 1990 allowed separation of the freshwater and saltwater components of recruitment in these fish and comparison with the historic record (Ward and Slaney 1988; Ward et al. 1989; Ward and Slaney 1993a; Ward 1996; Ward and McCubbing 1998). Results and conclusions from previous monitoring have been radically altered by recent changes in steelhead abundance, requiring a reanalysis.

Altered survivals of steelhead returning to the Keogh 
River, on northern Vancouver Island, were key to an explanation of the abundance trends and impacts of the 1990 ocean climate shift (Mantua et al. 1997; Smith and Ward 2000; Welch et al. 2000). Smith and Ward (2000) and Welch et al. (2000) demonstrated the relationship between smolt-to-adult survival of Keogh River steelhead and steelhead abundance trends over the British Columbia coast and found evidence for a recent sharp, widespread, and persistent decline in the number of steelhead in south-central regions of British Columbia. Walters and Ward (1998) documented parallel declines in steelhead, coho, and Atlantic salmon (Salmo salar) survivals, suggested the potential of a widespread response over the Northern Hemisphere, and showed that declines in freshwater production (steelhead smolts per spawner) had also occurred. The impact of climateinduced declines on both freshwater and marine survival and subsequent steelhead recruitment was not considered in these reports. Welch et al. (2000) implicated declines in ocean productivity, yet did not find a relationship between ocean upwelling in northern latitudes and steelhead abundance, while Smith and Ward (2000) did find a significant relationship between upwelling in the highly productive Coastal Upwelling Domain (British Columbia to California; Ware and McFarlane 1989) and steelhead abundance, as indexed by angler catch. Walters and Ward (1998) implicated ultraviolet-B radiation as a possible mechanism affecting freshwater life stages and early ocean survival, requiring further research.

Climate change has significant impacts on salmonid behaviour and survival. Canadian climate in 1998 was the warmest on record, in the warmest of decades (Environment Canada, http://www1.tor.ec.gc.ca/ccrm/bulletin/index.html). Links have been established among climate, large-scale oceanographic changes, and the ocean capacity for salmon (Brodeur and Ware 1992) and other fish (Ware and McFarlane 1989; Beamish 1993), as well as salmonid distribution and ocean temperature (Welch et al. 1998). Hare et al. (1999) related opposing variations in Alaska and west coast Pacific salmon catches to the Pacific Decadal Oscillation, 20- to 30-year-long regimes characterized by abrupt reversals. It has been argued that a warmer climatic regime has recently occurred, beginning in approximately 1990 (Beamish et al. 2000; Welch et al. 2000), but the mechanism of impact on salmonids remains unclear. Depending on the magnitude, these impacts may be substantial. Welch et al. (1998) predicted that in a warmer climate equivalent to two times $\mathrm{CO}_{2}$, the ocean distribution of many species of Pacific salmon would decline to half its present area by 2070 and the area of preferred temperature distribution in winter could completely disappear.

In this paper, I present three observations on steelhead survival and recruitment that have broad implications for the sustainable management of anadromous fish. First, I demonstrate that large changes in natural mortality rate in both freshwater and marine life stages may occur abruptly. Second, these changes may persist over decadal time periods. Third, I show that recruitment of Keogh River steelhead has dropped below the replacement level as a result of climateinduced declines in survival during their freshwater and marine life stages. The downward trend in steelhead returns is further confirmed by reexamining survival of steelhead in both their freshwater and marine life stages and through comparison with survival rates and relationships previously reported in Ward and Slaney (1988) and Ward et al. (1989). In addition, the revised conditions for recruitment of smolts and adults are examined at the current low spawner density and low return rates and in comparison with previous estimates in Ward and Slaney (1993a) and Ward (1996). Further research on causal mechanisms is encouraged, as well as mitigation during freshwater rearing to compensate for declines in both marine and freshwater survival.

\section{Materials and methods}

The Keogh River, draining into Queen Charlotte Strait near Port Hardy, B.C., is $35 \mathrm{~km}$ long and drains a watershed area of $130 \mathrm{~km}^{2}$. The watershed, more fully described in Ward and Slaney (1979), Irvine and Ward (1989), and Johnston et al. (1990), is in the coastal western hemlock biogeoclimatic zone, with mean annual discharge of $5.3 \mathrm{~m}^{3} \cdot \mathrm{s}^{-1}$ and an estimated winter maximum of $254 \mathrm{~m}^{3} \cdot \mathrm{s}^{-1}$. The Keogh River fish fence is situated $300 \mathrm{~m}$ upstream from the river mouth, at approximately the high tide mark, and has permitted virtually complete enumeration of downstream-migrant fish during spring, and accurate estimates of the steelhead spawners migrating upstream, since 1976.

Standard procedures for estimating numbers and ages of adult steelhead and methods of enumerating and sampling smolts at the Keogh River have been reported (Ward and Slaney 1988, 1990; Irvine and Ward 1989; Ward et al. 1989, 1990; Ward and McCubbing 1998) and are briefly described. Work in past years may have influenced smolt yield. Previous studies at the Keogh River included whole-river nutrient addition (Johnston et al. 1990; Slaney and Ward 1993), placement of stream habitat structures (Ward and Slaney 1993b; McCubbing and Ward 1997), net-pen rearing of steelhead smolts and studies of release time and location (Ward and Slaney 1990), and tagging studies on steelhead (Ward et al. 1990) and coho salmon (Irvine and Ward 1989). Of these, nutrient addition experiments were shown to positively influence smolt yield. The steelhead smolt release experiments from net-pen rearing were unlikely to have altered wild steelhead production, since the experimental period was brief, smolt releases and returns were in the lower reaches of the watershed, and broodstock selection was confined to wild native brood, all during a period of abundant wild fish escapement (i.e., at capacity; Ward 1996; Ardren 1999). Earlier work on habitat structures was not large enough in scale to alter smolt yield, and benefits to smolt yield from recent watershed restoration work were not expected until after 1999 (McCubbing and Ward 1997).

The total numbers of adult males and females were estimated separately by mark and recapture using the adjusted Petersen estimate (Ricker 1975; Ward and Slaney 1988, 1990). Upstreammigrant adults were captured and marked (December to May; a small hole was punched in the operculum), and then, steelhead kelts were captured during their postspawning downstream migration (March to June) and examined for marks. Typically, 50\% (SD $17 \%$ ) of the population was handled either as an upstream-migrant adult or unmarked kelt to provide confident estimates. Confidence limits on the male and female population estimates were calculated separately (Ricker 1975) and then combined to form lower and upper confidence limits that were, on average, 24 and $43 \%$ of the combined estimates, respectively (Ward and Slaney 1988; Ward et al. 1990). In 1997-1998, a Logie electronic counter was also used to enumerate upstream migrants, with $89 \%$ accuracy (Ward and McCubbing 1998).

Smolt enumeration and sampling were consistent annually. Fish captured in the smolt trap during spring were processed daily according to procedures in Ward and Slaney (1988), Ward et al. 
Fig. 1. Escapement estimates of steelhead adults to the Keogh River from 1976 to 1998 (bars) and the five-year running average (line).

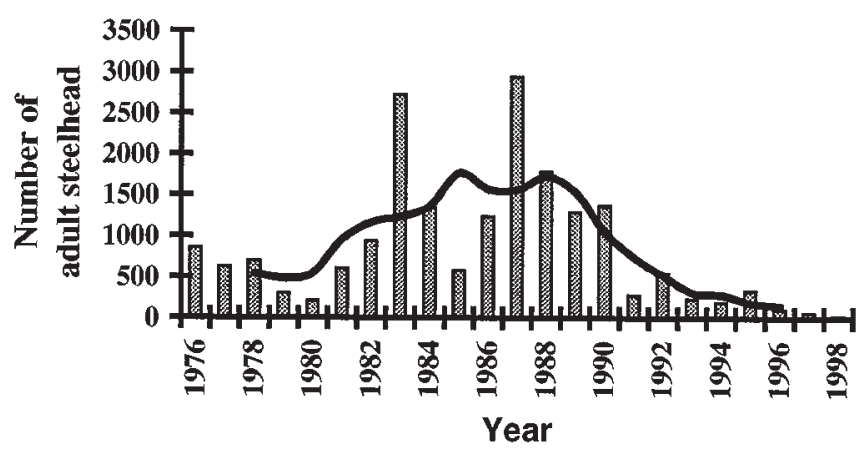

(1990), and Ward and McCubbing (1998). However, total smolt capture was incomplete in the springs of 1981, 1997, and 1998, due to high water flow resulting in some water flow over the fence. Estimated losses were early in the smolt migration timing and low ( $<5 \%$ of the total capture). Losses were calculated by mark and recapture during the event (smolts were marked with an upper caudal fin clip and released upstream) and based on partial counts during and total counts before and after the event. Flood events never occurred during the peak week of migration, which averaged May 25 (data on file). All fish captured were enumerated, and lengths and weights were randomly sampled throughout the trapping period. Scale samples from above the lateral line and behind the dorsal fin were taken from steelhead smolts in a sampling regime that was stratified according to fish size and migration time (Ricker 1975; Ward et al. 1989).

The relationship between the number of smolts and the number of adults returning was examined, as in Ward and Slaney (1988), but included data up to 1995 (smolts) and 1998 (adult returns) for a sample size of 19 smolt years versus 7 (Ward and Slaney 1988) or 15 (Ward 1996) in previous analyses. Repeat-spawning adults were excluded from the analysis. The linearity of the smolt and maidenrun adult relationship was tested with least squares regression. It had been demonstrated that steelhead survival during the marine phase was highly size dependent (Ward and Slaney 1988; Ward et al. 1989; Ward 1996). In this paper, the relationship between mean smolt size and smolt-to-adult survival was further examined to include recent results and test previous conclusions.

Steelhead smolt yield was tabulated into the brood year of origin based on smolt age and total smolt yield and compared with the spawner abundance (Ward and Slaney 1993a; Ward 1996). A Beverton-Holt curve (Hilborn and Walters 1992) was fitted to data on smolt recruitment from smolts derived from years of natural nutrient level. Four smolt broods (1982 to 1985) were wholly or partially influenced by whole-river nutrient addition through increased growth, abundance, and subsequent smolt yield, the amount dependent on the number of years the fish had spent in the river and the coincidence with nutrient addition (Johnston et al. 1990; Slaney and Ward 1993). The Beverton-Holt curve was forced through only one of these data points (1984), since it represented the only smolt group where all juvenile ages were present during fertilizer additions. This is an imprecise estimate of expected yield with fertilizer addition until a longer-term study is completed (i.e., a better estimate of smolt yield under enhanced nutrient conditions would require several more years of fertilizer application and smolt monitoring). Smolts per spawner in relation to spawner numbers were examined for the 1976 to 1986 period with and without nutrient addition and for the less productive period from 1987 to 1994 .

The fit of the recruitment model to the data was determined by the amount of variation explained by the nonlinear least squares regression estimates of smolt recruitment parameters. The mean cor- rected $r^{2}$ statistic from nonlinear estimation methods (Systat 7.0 for Windows, SPSS Inc., Chicago, Ill.) was derived from the GaussNewton algorithm, using the Beverton-Holt recruitment model of Hilborn and Walters (1992) for spawners and smolt recruits. First, all years were included in the analysis (1976 to 1994 broods), and residuals were examined for their temporal distribution. Separate estimates of the smolt recruitment parameters were calculated for the data from 1976 to 1987 , excluding those from years of fertlizer addition, and then for the 1987 to 1994 period.

Jackknife estimates of smolt recruitment parameters were calculated from the data from broods 1976 to 1986 (excluding years of fertilizer addition) and data from 1987 to 1994 according to methods in Hilborn and Walters (1992). The coefficients of variation for the jackknife estimates of the asymptotic recruitment $(\alpha)$ and the number of spawners required to produce $\alpha / 2(\beta)$ were determined. In addition, the jackknife estimates were standardized to zero mean and their temporal pattern examined for variation (SEs) around the standardized mean.

Adult recruits per spawner were difficult to estimate because of the complex age structure of adult returns. Adult returns could potentially contain 12 age-classes, i.e., from 2 to 5 years in freshwater and from 1 to 3 years in the ocean, plus repeat spawners. Separation of adult males and females into these age groups was not possible in some years due to low return and poor sample size. However, calculation of marine survival was reliably based on smolt counts, adult numbers, and the number of years that adults had spent at sea. Smolt counts and ageing of smolts' scales allowed tabulation into their respective brood years and provided a direct estimate of smolt recruits as a function of spawner density to which were applied smolt-to-adult survival rates relevant to each group.

Three recruitment scenarios were considered for the spawner-tosmolt life stage, based on the distribution of residuals from the overall Beverton-Holt curve, to which were added two scenarios of survival in the smolt-to-adult stage to generate adult recruits. Thus, three levels of production in freshwater and two regimes of survival during the marine life stage produced six curves. Recruitment curves were based on the spawner-to-smolt recruitment parameters estimated for $(i)$ natural conditions in freshwater from 1976 to 1986, (ii) conditions of nutrient addition, and (iii) freshwater rearing conditions after 1987. Adult recruits (excluding repeat spawners) were calculated by applying smolt-to-adult survival rates of either 15 or $4 \%$ (representing the average rates for 1976 to 1989 and 1990 to 1995 , respectively). Adult steelhead recruitment for these scenarios was examined in relation to levels required for at least adult replacement.

\section{Results}

Adult steelhead run sizes have declined by an order of magnitude, from values that were typically $>1000$ spawners during the mid-1980s to numbers that are now $<100$ (Fig. 1). The 5-year running average, which smoothed abundance trends in relation to average age (5.3 years), clearly indicated a period of increase and a decade of high abundance followed by rapid decline. The average run size from 1976 to 1990 was 1168 (SE 207), while the period 1991 to 1998 averaged 223 (SE 59) wild spawners, a highly significant difference $(t$ test). A sharp and persistent decline in run strength was particularly evident after 1990 . In the winter runs of 1997 and 1998, steelhead spawners numbered 60 and 30 adults in total, respectively.

There has been a fourfold decline in smolt-to-adult survival. The number of years that fish had spent in salt water was determined from their scales, which allowed tabulation 
Fig. 2. Relationship between subsequent steelhead adult returns from smolts of the Keogh River for the period 1976 to 1989 (broken line, diamonds) and 1990 to 1995 (solid line, squares).

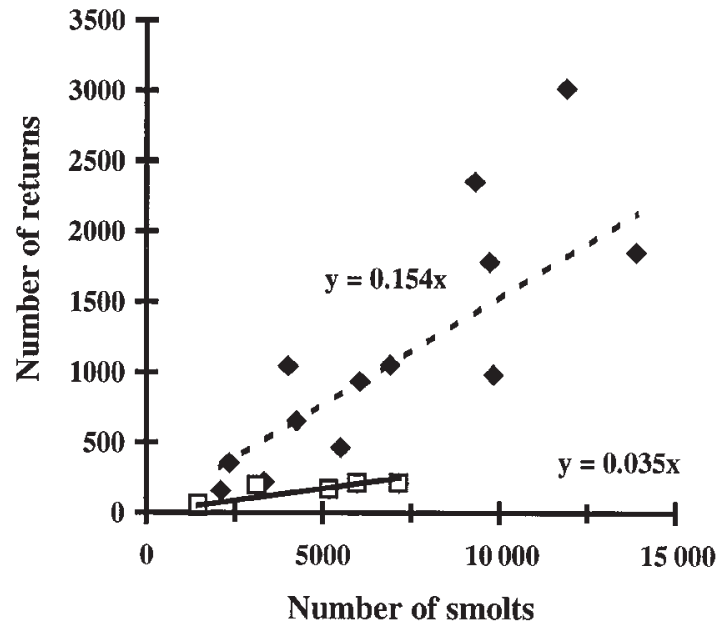

Fig. 3. Smolt-to-adult survival of Keogh River steelhead and the relationship to mean smolt length. From 1976 to 1989, survivals (broken line, diamonds) were positively and significantly $\left(r^{2}=\right.$ 0.85) related to mean smolt size (Ward and Slaney 1988; Ward et al. 1989). Smolts of 1982 and 1985 experienced higher than expected survivals in relation to El Niño events (squares) (Ward 1996). Recent survivals (1990 to 1995 ; circles) were no longer related to mean smolt size (no significant difference from a slope of zero) and significantly lower than previous values $(p<0.05$, ANOVA).

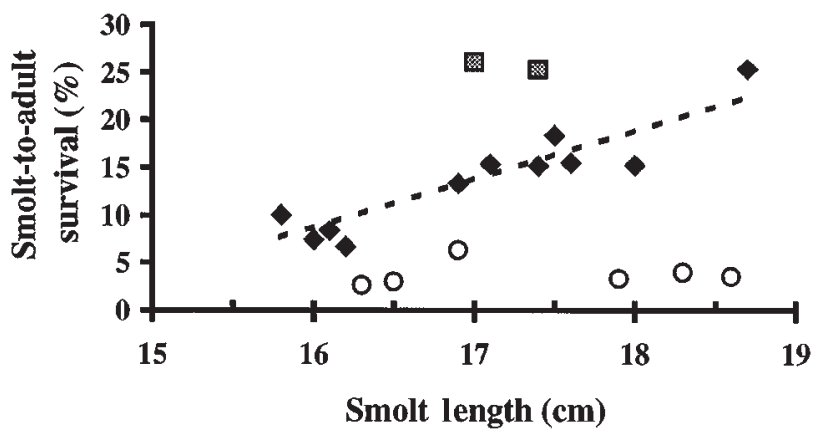

of returns into their respective smolt groups. The relationship between adult returns, excluding repeat spawners, and smolt yield averaged 15\% (SE 1.9) for the period 1976 to 1989 but only 4\% (SE 0.5) for the period 1990 to 1995 . The slopes of the relationships from the two time periods were significantly different (Fig. 2).

The previously established relationship between smolt size and smolt-to-adult survival in steelhead no longer applied after 1990. While data were limited $(n=6)$, the slope was not significantly different from zero for the 1990 to 1995 smolts (Fig. 3) versus a positive slope of 5 in Ward (1996). The expected survivals, based on the previous regime and the range in mean smolt size from 1990 to 1995 , was from 10 to $20 \%$, but instead averaged $<4 \%$. The latter data set includes values from an El Niño event in 1992 that did not generate higher than expected survival in steelhead, as had previous events (1982 and 1985; Fig. 3).

Only $45 \%$ of the variation in the overall relationship of
Fig. 4. Smolt recruitment from steelhead spawners for 1976 to 1994 in the Keogh River including natural smolt yield from 1976 to 1986 broods (diamonds) and smolt yield from whole-river nutrient addition experiments (squares) on 1982 to 1985 broods (Slaney and Ward 1993). Circles indicate lower smolt recruitment after the 1987 escapement, the lowest of which were from the most recent brood years, 1991 to 1994.

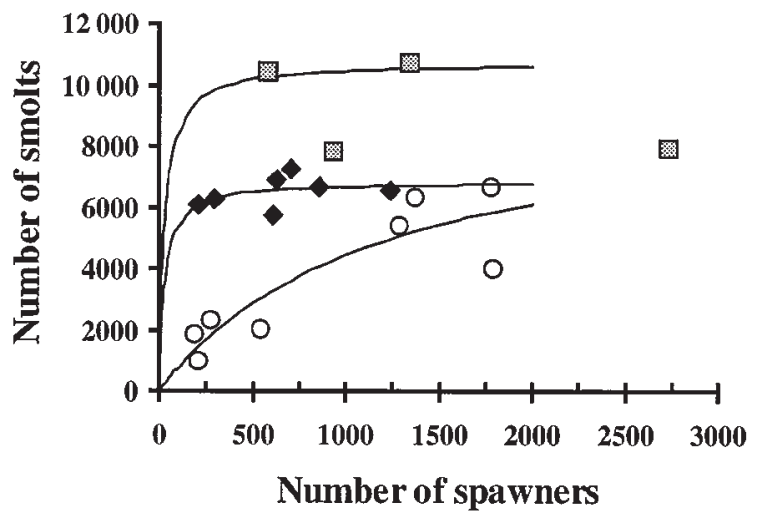

smolt recruits and spawners was explained by the BevertonHolt recruitment curve predicted from nonlinear least squares regression. Residuals were distributed according to a time series where points from 1987 to 1994 fell below the curve, data points from 1976 to 1986 were on or above the line, and points from years of nutrient addition were far above the line. Excluding data points from years of nutrient addition (1982 to 1985) resulted in a slightly better fit (mean corrected $r^{2}=0.49$ ). Separate smolt recruitment curves for the two time series 1976 to 1986 and 1987 to 1994 provided better results. In the first series, $97 \%$ of the variation in the relationship of spawners and smolts was explained by the Beverton-Holt curve and $79 \%$ of the variation for the data from the second series or later years. The smolt recruits from the 1987 brood year (1800 spawners) were the first group to demonstrate a decline (to 4027 smolts), whereas $>7000$ were expected from past observations (Fig. 4).

Three scenarios emerged from examination of the smolt yield of the Keogh River steelhead in relation to the spawner population size (Fig. 4). First, under natural conditions during 1976 to 1986, the maximum yield of smolts was 6866, and the number of spawners required to achieve half of that asymptotic yield ( $\beta$ ) was 28 , based on nonlinear least squares regression parameter estimates. Second, under conditions of nutrient enrichment, the maximum smolt yield $(\alpha)$ rose to approximately 10500 smolts, based on four years of nutrient enrichment and forcing the curve through the one data point where smolts were reared totally under conditions of fertilizer addition (the actual asymptote with fertilization will remain unknown due to the short experimental period). However, smolts per spawner then declined below values expected from earlier (1976 to 1986) estimates, beginning with the 1987 brood. A third, lower recruitment relationship was evident for broods from 1987 to 1994 . Recruitment analysis using only the latter eight data points indicated decreased productivity during the freshwater life stage, where now, $\beta$ was estimated at 1175 (Fig. 4). This theoretical number of spawners is unachievable under current levels of survival and return (Fig. 1).

Jackknife estimates of recruitment parameters for the data 
from years of no fertilizer addition were calculated. The coefficients of variation in jackknife estimates of $\alpha$ and $\beta$ were 2.1 and16.5, respectively, for the 1976 to 1986 results and 26.2 and 41.7, respectively, for the 1987 to 1994 results. Thus, the estimates of the slopes were more variable than the estimates of the asymptotes, due to insufficient data at low spawner levels. Variability in standardized values of maximum recruitment $(\alpha)$ from jackknife estimates was typically <0.5 SE. Exceptions occurred when the 1978 and 1981 data points were excluded, which placed the standardized values 1.5 SE below and above the standardized mean, respectively, and indicated that the curve shape was strongly influenced by these data. In the 1987 to 1994 data set, exclusion of the 1987 data point set the standardized $\alpha$ value 2.3 SE above the standardized mean $\alpha$, while the others were $<0.8$ SE. Similarly, $\beta$ was 2.3 SE above the standardized mean $\beta$ when the 1987 data point was removed in the jackknife estimation procedure, while the remaining estimates were within $\pm 1 \mathrm{SE}$ of the mean estimate. Thus, 1987 data strongly influenced the curve shape (downward) and may have represented particularly poor conditions for freshwater rearing compared with other years in this group.

Large differences in smolt yield per spawner were evident under the three scenarios of smolt recruitment and as a function of the number of spawners. For example, the expected natural production of 300 spawners (equivalent to $140 \%$ of the previous estimate of spawners at maximum sustained yield; Ward 1996) from the period 1976 to 1986 was 21 smolt recruits per spawner, whereas during the 1990s, only six smolts per spawner were expected. Similarly, 1000 spawners (i.e., the previous maximum recruitment; Ward 1996) might have provided, on average, nine, seven, and four smolts per spawner under fertilizer addition, natural, and more recent (lower) production regimes in freshwater, respectively. Lowest smolt yield was from the 1991 to 1994 period, the most recent data. Smolts per spawner from the latter broods were, on average, $70 \%$ lower than the estimated recruitment from equivalent escapement in the previous regime (Fig. 4). Adult runs have been $<100$ fish in each of the past three seasons (Fig. 1). The smolt yield from this low level of spawning escapement is unknown, since smolts are yet to be counted, but was estimated at $<1000$ smolts based on the 1987 to 1994 spawner and smolt recruitment relationship and assuming no depensatory mortality.

Three possible smolt recruitment relationships were considered (Fig. 4), and to these were applied two regimes of smolt-to-adult survival, 15 and $4 \%$ (Fig. 2). In the first case (1976 to 1986), the Keogh River had an unfished equilibrium recruitment of approximately 1000 adults (Fig. 5). Application of inorganic fertilizer to the system boosted smolt yield, from which a smolt recruitment relationship was estimated and to which the same survival rate $(15 \%)$ was applied. A $50 \%$ increase in smolt and adult recruitment has been estimated as the potential benefit of nutrient addition (Fig. 5, uppermost curve). However, the third case, which included the recent reduction in freshwater productivity, suggested that at smolt-to-adult survival rates of $15 \%$ or less, the adult recruitment was at or below replacement (Fig. 5). Recruits were well below replacement by application of marine survival rates of $4 \%$ to these three smolt recruitment
Fig. 5. Recruitment scenarios for Keogh River steelhead based on three levels of production in freshwater and two regimes of survival during the marine life stage. The top curve (broken line, squares) depicts smolt yield under conditions of whole-river nutrient addition and smolt-to-adult survival (SA) of 15\%. Natural production of smolts through the late 1970s and 1980s and SA = $15 \%$, the average for this period, are represented by the broken line and diamonds (Ward 1996). Reduction in recruitment in the freshwater life stage alone based on smolts per spawner values from 1987 to 1994 , and $\mathrm{SA}=15 \%$, places the number of adult recruits (broken line, circles) at or below the line of replacement (diagonal line). A change in the average SA to $4 \%$ (as in the 1990s), but with nutrient addition under freshwater rearing conditions of the late 1970s and 1980s, suggests a recruitment curve with lower capacity (solid line, squares) but above replacement when spawners are $<400$. That capacity is lower again without nutrient addition and $\mathrm{SA}=4 \%$ (solid line, diamonds). The current scenario is likely to resemble the lower curve (solid line, circles), where survival conditions in both freshwater and marine life stages during the 1990s have resulted in steelhead recruitment that is far below replacement. Adult escapement has declined to $<100$ spawners in recent years, or one tenth the average run size of the previous decade.

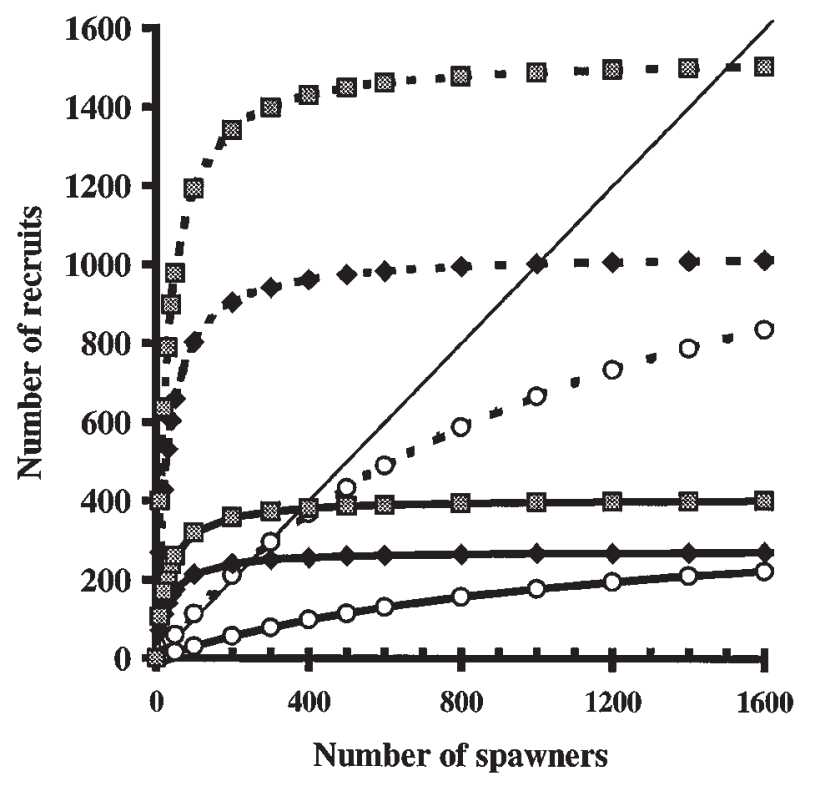

scenarios. The lowest of the six curves in Fig. 5 represents the current scenario.

The current reduced survival in both freshwater and marine life stages placed steelhead recruitment well below the line of replacement in the Beverton-Holt recruitment curve (Fig. 5). Results of monitoring the Keogh River population confirmed that survivals have been consistently low during both life stages through the 1990s and suggest that at current escapements, smolt recruitment would continue to decline. At current rates of survival in the ocean $(<4 \%)$ and freshwater (the estimated density-independent survival from egg to smolt averaged <0.34\% from the 1990 to 1994 brood), it will be but two or three generations (10-16 years) before the population collapses entirely or contains only a few remnant fish. 


\section{Discussion}

Three scenarios of freshwater survival for Keogh River steelhead smolts were considered, and two possible marine survival scenarios beyond the smolt stage based on data obtained at the Keogh River from 1976 to 1998. From the freshwater life stage, smolts were considered to be derived either from natural conditions of the 1980s regime (1976 to 1986), from conditions of nutrient enrichment (1982 to 1985), or from conditions post-1987 (the 1990s regime). In the marine life stage, smolt-to-adult survivals were based on the average of values from 1976 to 1989 and from 1990 to 1995. Arguably, none of these scenarios was supported by adequate data (i.e., sample size was small), and iteroparous steelhead were inappropriate for standard recruitment analysis (Hilborn and Walters 1992). Nevertheless, the available information strongly suggested that changes lowering production have occurred in both freshwater and marine life stages of steelhead, which placed recruitment at new and much lower productivity and capacity, below replacement and at very low abundance $(<10 \%$ of freshwater habitat capability).

Uncertainty in parameter estimates was evident, as in most recruitment analyses. A better jackknife procedure would remove data from cohorts that shared the stream in adjacent age-classes to reestimate the range in parameter estimates. For example, two broods (1979 and 1980) were low in spawner abundance (299 and 209, respectively) (Fig. 1), yet each recruited $>6000$ smolts and had high leverage in development of the recruitment curve for the 1976 to 1986 group. Removal of one or the other of these broods, whose young were present in the river at the same time but at different ages, had minor impact on jackknife estimates, whereas removal of both produced a significantly lower recruitment curve. However, reliable jackknife estimates based on removal of adjacent cohorts would require more years of data than were available from Keogh steelhead studies. Other problems associated with recruitment analysis in steelhead have been discussed (Ward 1996), including lack of sufficient data at low spawner density and the problems of including repeat spawners in the total spawner abundance, but no clear mechanism to include iteroparity in the smolt and subsequent adult recruitment. Further work is required to explore the impact on recruitment in steelhead given variation in population fecundity and survival through all life stages, and under the range of possible production and regimes of production within their geographic distribution, but longterm data such as those provided at the Keogh River are lacking (Snow Creek, Washington, is another wild steelhead population monitored in the same manner, with parallels in marine survival; Walters and Ward 1998).

The period 1987 to 1990 may have been transitional (downwards); thus, recruitment parameter estimates that included data from then may have been too conservative. The lowered regime of recruitment may be still lower than estimated by the bottom curve in Fig. 5 but will be poorly defined until additional information has been obtained through continued fence operation and assuming that conditions remain static. Of course, it is preferred that conditions would improve and we would never obtain recruitment estimates under conditions of low productivity and low escapement. Even if production had decreased only in the marine life stage, asymptotic recruitment was much reduced, to approximately 8 from 40 fish $\cdot \mathrm{km}^{-1}$. The additional impact from lower freshwater production has resulted in returns that are now $<2$ spawners $\cdot \mathrm{km}^{-1}$. Mitigation that increases production in freshwater is required to offset this extinction trajectory. Opportunities to augment marine production are nonexistent.

Increased production through mitigation may not assist as much as might be expected if the population has experienced an extinction vortex, i.e., the population genetics and subsequent fitness have been negatively altered by low spawner abundance. Ardren (1999) discussed the possibility that both Snow Creek and Keogh River steelhead populations had reached levels of a potential extinction vortex. Continued monitoring, including population genetics, is essential for decisions concerning more stringent management actions and to allow detection of recovery or further decline in either freshwater or marine phases of the life history. Further research is required to assess critical levels of steelhead returns where an extinction vortex may become a concern.

Not only had the relationship between smolts and adults changed after 1990, variation within the relationship was no longer explained by smolt size, as it had been previously (Ward and Slaney 1988; Ward et al. 1989). There is no clear explanation for this. Welch et al. (2000) suggested that reduced growth under warmer oceanic conditions and lower trophic productivity may have resulted in longer exposure to predators, and therefore higher mortality. Nevertheless, one might still expect larger smolts to survive at higher rates than their smaller cohorts. Walters and Ward (1998) suggested that the physiological process of smoltification might have been affected by increased ultraviolet radiation during stream rearing. For the latter to alter the smolt size and survival relationship in the manner indicated, larger, and presumably older, smolts would have had to have been more affected than smaller, younger ones, through longer exposure. Alternatively, conditions for freshwater rearing may have been altered by climate changes (temperature increase, flow alteration, insect production), which in turn could have reduced smolt condition, energy reserves, and subsequent survival. Examining lipid content in smolt samples pre- and post-1990 might test the latter, but again, larger smolts would have had to have been disproportionately affected to explain the current lack of a relationship between size and survival. It remains to be shown that hatchery steelhead smolts display the same change in their size-survival relationship as seen in wild steelhead smolts of the Keogh River.

During 1982 and 1985 El Niño events, steelhead survival in the ocean was double that expected based on smolt size (Fig. 3). However, a similar result was not evident for 1992 smolts, which instead experienced $97 \%$ mortality before return. Ocean conditions were generally cooler prior to and during the previous El Niños, while the 1992 event occurred in ocean conditions of the northern Pacific that were already warmer than the previous period (Mantua et al. 1997). Through an unidentified ecological process perhaps related to these warmer conditions, steelhead survival declined, whereas in the recent past, similar events were associated with steelhead smolt survivals that exceeded $25 \%$. A brief El 
Niño during cool oceanic conditions may have been conducive to production in areas utilized by steelhead, whereas an El Niño event when already relatively warm may have resulted in a less stable and less productive oceanic water column, as suggested in Welch et al. (2000). Alternatively, steelhead survival has no connection to these events, and some other pathologic, oceanographic, or demonic intrusion has occurred.

Environment Canada's Atmospheric Environmental Service monitors climate change in Canada and the Northern Hemisphere. A number of trends were evident since the 1900s, including significant increases during the 1980s and 1990 s in the frequency of winter storms and intensity of summer droughts (Environment Canada, Atmospheric Environmental Service, Port Hardy Weather Station; Francis and Hengeveld 1998; http://www1.tor.ec.gc.ca/ccrm/bulletin/index. html). The latter would decrease salmonid survival and production through habitat alteration, dislodgment of fish, decreased habitat capacity, etc., as predicted by Northcote (1992). Such changes may explain the declines observed since 1990 in Keogh steelhead production, as well as the parallel and dramatic declines observed for all other Keogh fish emigrants (coho salmon, Dolly Varden (Salvelinus malma), cottids Cottus aleuticus and Cottus asper, lampreys Lampetra tridentata and Lampetra ayresi) reported by Ward and McCubbing (1998). Sea-run cutthroat trout (Oncorhynchus clarki), perhaps capable of filling the ecological niche largely vacated by steelhead and Dolly Varden, were numerically higher at the Keogh River fish fence through the 1990 s, but the difference was not statistically significant and never more than 30 adults or 250 smolts. To date, there is no clear evidence that the climate change has benefited one species over another.

It was with little surprise that documented declines in marine conditions for salmonids (Beamish et al. 2000; Welch et al. 2000) were accompanied by declines in productivity during freshwater rearing. There are undoubtedly strong linkages between oceanic and atmospheric climate of the eastern Pacific area; the same storm and drought events that reduced freshwater rearing altered the marine ecosystem (e.g., change to the Aleutian Low was coincident with a change in Fraser River flow in spring; Beamish et al. 2000). In addition, freshwater and marine life stages are linked through biological traits such as adult size and fecundity upon return and smolt size and condition upon emigration, as well as carcass decomposition.

Not only were other fish species in the Keogh River likewise affected by declines in freshwater and (or) marine survival, recent literature indicated similar scenarios over a broader geographic area. Smith and Ward (2000) and Welch et al. (2000) found that steelhead abundance trends for populations from the east coast of Vancouver Island and the British Columbia south coast were well matched to trends in marine survival rates of Keogh River smolts and that these rates paralleled coho salmon marine survivals reported in Beamish et al. (2000). Walters and Ward (1998) noted profound declines in marine survival rates of steelhead, coho salmon, chinook salmon (Oncorhynchus tshawytscha), and Atlantic salmon since the mid-1980s in North America. Fisheries for steelhead and coho salmon in British Columbia, and particularly within the Georgia Basin and on the east coast of Vancouver Island, were closed or much reduced in 1998 due to low survivals and population size. It is highly unlikely, therefore, that declining abundance at the Keogh was a result of fish fence operations. The structure and methods of operation have not been changed during periods of increased or decreased fish abundance, and trends in steelhead abundance at the Keogh were parallel to changes elsewhere. Further work is required to more fully examine the geographical and biological extent of these unsettling trends.

For other salmonids likewise affected, there is a need for intensive review of status, a precautionary management approach, and reduced harvest rates where justified. For Keogh steelhead, the previous estimate of habitat capacity (7000 smolts; Ward and Slaney 1993a) cannot be attained at current levels of production from the freshwater and marine environments. Thus, although a salmonid population is producing at its maximum capability under current conditions of low survival, reduced habitat utilization and juvenile density is expected and has been observed in steelhead (McCubbing and Ward 1997). There is a need to examine juvenile density and smolt yield in other salmonid species (e.g., coho and chinook salmon) that rear in streams for evidence of reduced habitat utilization as an indicator of reduced survival rates and a lower overall productive capacity. Continued harvest may eventually eliminate such populations, contribute to further decline, or continue to maintain them at low levels of abundance.

Reduced salmonid abundance in itself has an effect on stream carrying capacity, providing further linkage of freshwater and marine life stages. Larkin and Slaney (1997) examined Pacific salmon escapement data for unenhanced streams and found declines in marine-derived nutrient influx. They concluded that the effects of nutrient loss via the process of oligotrophication seriously threaten freshwater stocks, in a negative feedback loop. It is possible that part of the decline in salmonid yield from the freshwater life history observed at the Keogh River may be attributed to declines in salmon carcass abundance, thus lowering both the carrying capacity and trophic productivity of the watershed. Salmon carcass declines have likely continued since publication of their results. The density-independent productivity of steelhead at low abundance has not been as high as was predicted from earlier recruitment analysis. Declines in productivity may have been associated with lower marine-derived nutrients, but this is difficult to determine, since salmon escapement counts in the Keogh River were unreliable prior to installation of the electronic resistivity fish counter in 1997 (Ward and McCubbing 1998).

The multistage stock-recruit model described by Moussali and Hilborn (1986) demonstrated that cumulative capacity was a function of productivity and habitat, yet harvest was independent of capacity. The latter required information on the productivity of the stock through successive life stages. Thus, an examination of the effect of variable survival must consider the cumulative effects through these life stages to adult recruits. The complexity of recruitment interactions and the questionable and difficult application of recruitment analysis to steelhead argue for maintenance of an index management system where the key components of life history are monitored annually. One such site for steelhead is 
the Keogh River, but clearly, one site is inadequate to detect trends coast-wide. There is a need to examine trends in steelhead abundance and select sites that reflect regional groups, such as those identified by Smith et al. (2000). Work at the Keogh River suggests that minimal variables to monitor to obtain key parameters of productivity and capacity include adult escapement and age structure, juvenile abundance and capability, and smolt yield tabulated by age group.

Recent restrictive fishing regulations for British Columbia steelhead and coho salmon because of very low abundance suggest that earlier stock status reviews would be too optimistic if applied today. Stock status reports on salmonid populations for the North American west coast of the Pacific Ocean, including Washington, Oregon, California, British Columbia, and Alaska, list numerous examples of populations that were of concern, rare, threatened, or endangered (Nehlsen et al. 1991; Baker et al. 1996; Slaney et al. 1996). These lists were largest for southern stocks. Had these lists been based on more recent information, they might have been substantially longer, since stock assessments indicating low abundance and subsequent reduced harvests have become issues on the west coast, particularly for coho salmon in the latter half of the 1990s.

There seems little that may be done to augment marine survival, other than to attempt to more fully comprehend the extent and mechanism of impact. Diligent habitat protection and mitigation to augment freshwater survival may assist in the interim. Recovery plans are currently under development for steelhead in streams of the east coast of Vancouver Island (C. Wightman, British Columbia Ministry of Environment, Lands and Parks, Nanaimo, B.C., personal communication) and for Canadian coho salmon (http://www. pac.dfo.ca/comm/pages/cohoresponse/cohoresp.htm). British Columbia's plans include experiments in the use of hatchery steelhead collected as wild native smolts, reared to maturity, spawned, and their progeny released into vacant habitat as fry or at river mouths as hatchery smolts. Fortunately, results of nutrient addition experiments within the Keogh River and elsewhere (Ashley and Slaney 1997) and other stream rehabilitation techniques (McCubbing and Ward 1997) indicate that such attempts to increase survival may assist towards maintaining populations, perhaps above the replacement level, until freshwater and marine conditions recover naturally, if they do.

\section{Acknowledgements}

Many assisted in Keogh River steelhead studies; their support and effort was very much appreciated. In particular, I gratefully acknowledge D. McCubbing, C. Melville, all the Keogh River fish fence crews, the Northern Vancouver Island Salmonid Enhancement Association, R. Land, P. Slaney, and C. Wightman. Recent support has been provided by the British Columbia Ministry of Fisheries, British Columbia's Habitat Conservation Trust Fund, Forest Renewal, British Columbia's Watershed Restoration Program, the British Columbia Ministry of Environment, Lands and Parks, and Federal Fisheries' Habitat Restoration and Salmon Enhancement Program. The much-appreciated reviews and suggestions from K. Ashley, C. Wightman, D. Welch, and B.
Smith improved earlier drafts, as did the subsequent helpful comments from reviewers T.G. Northcote and M. Chilcote.

\section{References}

Ardren, W.R. 1999. Effective number of breeders, rates of loss of genetic variability, and population productivity in two steelhead trout populations: implications for conservation and restoration. Ph.D. dissertation, University of Minnesota, St. Paul, Minn.

Ashley, K.I.A., and Slaney, P.A. 1997. Accelerating recovery of stream, river and pond productivity by low-level nutrient replacement. In Fish habitat rehabilitation procedures. Edited by P.A. Slaney and D. Zaldokas. B.C. Watershed Restoration Tech. Circ. No. 9. pp. 13-1 to 13-24.

Baker, T.T., Wertheimer, A.C., Burkett, R.D., Dunlap, R., Eggers, D.M., Fritts, E.I., Gharrett, A.J., Holmes, R.A., and Wilmot, R.L. 1996. Status of Pacific salmon and steelhead escapements in Southeastern Alaska. Fisheries (Bethesda), 21: 6-18.

Beamish, R.J. 1993. Climate and exceptional fish production off the west coast of North America. Can. J. Fish. Aquat. Sci. 50: 2270-2291.

Beamish, R.J., Noakes, D., McFarlane, G., Pinnix, W., Sweeting, R., and King, J. 2000. Trends in coho marine survival in relation to the regime concept. Fish. Oceanogr. In press.

Brodeur, R.D., and Ware, D.M. 1992. Interannual and interdecadal changes in zooplankton biomass in the subarctic Pacific Ocean. Fish. Oceanogr. 1: 32-38.

Francis, D., and Hengeveld, H. 1998. Extreme weather and climate change. Environment Canada Atmospheric Environment Service Catalogue No. En57-27/1998-01E. (http://www.ec.gc.ca/climate/ whatsnew/index.html)

Hare, S.R., Mantua, N.J., and Francis, R.C. 1999. Inverse production regimes: Alaska and west coast Pacific salmon. Fisheries (Bethesda), 24: 6-14.

Hilborn, R., and Walters, C.J. 1992. Quantitative fisheries stock assessment: choice, dynamics and uncertainty. Chapman and Hall, New York.

Irvine, J.R., and Ward, B.R. 1989. Patterns of timing and size of wild coho salmon smolts (Oncorhynchus kisutch) migrating from the Keogh River watershed on northern Vancouver Island. Can. J. Fish. Aquat. Sci. 46: 1086-1094.

Johnston, N.T., Perrin, C.J., Slaney, P.A., and Ward, B.R. 1990. Increased juvenile salmonid growth by whole-river fertilization. Can. J. Fish. Aquat. Sci. 47: 862-872.

Larkin, G.A., and Slaney, P.A. 1997. Implications of trends in marine-derived nutrient influx to south coastal British Columbia salmonid production. Fisheries (Bethesda), 22: 16-24.

Mantua, N.J., Hare, S.R., Zhang, Y., Wallace, J.M., and Francis, R.C. 1997. A Pacific interdecadal climate oscillation with impacts on salmon production. Bull. Am. Meteorol. Soc. 78: 1069-1079.

McCubbing, D.J.F., and Ward, B.R. 1997. The Keogh and Waukwass rivers paired watershed study for B.C.'s Watershed Restoration Program: juvenile salmonid enumeration and growth 1997. B.C. Watershed Restoration Proj. Rep. No. 6.

Moussali, E., and Hilborn, R. 1986. Optimal stock size and harvest rate in multistage life history models. Can. J. Fish. Aquat. Sci. 43: $135-141$.

Nehlsen, W., Williams, J.E., and Lichatowich, J.A. 1991. Pacific salmon at the crossroads: stocks at risk from California, Oregon, Idaho, and Washington. Fisheries (Bethesda), 16: 4-20.

Northcote, T.G.N. 1992. Prediction and assessment of potential effects of global environmental change on freshwater sport fish habitat in British Columbia. GeoJournal, 28: 39-49. 
Ricker, W.E. 1975. Computation and interpretation of biological statistics of fish populations. Bull. Fish. Res. Board Can. No. 191.

Slaney, P.A., and Ward, B.R. 1993. Experimental fertilization of nutrient deficient streams in British Columbia. In Le développment du saumon atlantique au Québec : connaître les règles du jeu pour réussir. Edited by G. Shooner and S. Asselin. Colloque international de la Fédération québécoise pour le saumon atlantique, Québec, décembre 1992. Collect. Salmo salar No. 1. pp. 128-141.

Slaney, T.L., Hyatt, K.D., Northcote, T.G., and Fielden, R.J. 1996. Status of anadromous salmon and trout in British Columbia and Yukon. Fisheries (Bethesda), 21: 20-35.

Smith, B.D., and Ward, B.R. 2000. Trends in adult wild steelhead (Oncorhynchus mykiss) abundance for coastal regions of British Columbia support the variable marine survival hypothesis. Can. J. Fish. Aquat. Sci. 57: 271-284.

Smith, B.D., Ward, B.R., and Welch, D.W. 2000. Trends in wild adult steelhead (Oncorhynchus mykiss) abundance in British Columbia as indexed by angler success. Can. J. Fish. Aquat. Sci. 57: $255-270$.

Walters, C.J, and Ward, B.R. 1998. Is solar UV radiation responsible for declines in marine survival rates of anadromous salmonids that rear in small streams? Can. J. Fish. Aquat. Sci. 55: 2533-2538.

Ward, B.R. 1996. Population dynamics of steelhead in a coastal stream, the Keogh River, British Columbia. In Stock assessment in inland fisheries. Edited by I. Cowx. Fishing News Books, Blackwell Scientific Publications, Oxford, U.K. pp. 308-323.

Ward, B.R., and McCubbing, D.J.F. 1998. Adult steelhead and salmonid smolts at the Keogh River during spring 1998 and comparison to the historic record. B.C. Fish. Tech. Circ. No. 102.

Ward, B.R., and Slaney, P.A. 1979. Evaluation of in-stream enhancement structures for the production of juvenile steelhead trout and coho salmon in the Keogh River: progress 1977 and 1978. B.C. Fish. Tech. Circ. No. 45.

Ward, B.R., and Slaney, P.A. 1988. Life history and smolt-to-adult survival of Keogh River steelhead trout (Salmo gairdneri) and the relationship to smolt size. Can. J. Fish. Aquat. Sci. 45: 1110-1122.
Ward, B.R., and Slaney, P.A. 1990. Returns of pen-reared steelhead trout from riverine, estuarine, and marine releases. Trans. Am. Fish. Soc. 119: 492-499.

Ward, B.R., and Slaney, P.A. 1993a. Egg-to-smolt survival and fryto-smolt density dependence of Keogh River steelhead. In Production of juvenile Atlantic salmon, Salmo salar, in natural waters. Edited by R.J. Gibson and R.E. Cutting. Can. Spec. Publ. Fish. Aquat. Sci. No. 118. pp. 209-217.

Ward, B.R., and Slaney, P.A. 1993b. Habitat manipulations for the rearing of fish in British Columbia. In Le développment du Saumon atlantique au Québec : connaître les règles du jeu pour réussir. Edited by G. Shooner and S. Asselin. Colloque international de la Fédération québécoise pour le saumon atlantique, Québec, décembre 1992. Collect. Salmo salar No. 1. pp. 142-148.

Ward, B.R., and Wightman, J.C. 1989. Monitoring steelhead trout at the Keogh River as an index of stock status and smolt-to-adult survival: correlations with other data sources. B.C. Fish. Manage. Rep. No. 95.

Ward, B.R., Slaney, P.A., Facchin, A.R., and Land, R.W. 1989. Size-biased survival in steelhead trout: back-calculated lengths from adults' scales compared to migrating smolts at the Keogh River, B.C. Can. J. Fish. Aquat. Sci. 46: 1853-1858.

Ward, B.R., Burrows, J.A., and Quamme, D.L. 1990. Adult steelhead population size and salmonid migrants of the Keogh River during the spring, 1990. B.C. Tech. Circ. No. 89.

Ware, D.M., and McFarlane, G.A. 1989. Fisheries production domains in the Northeast Pacific Ocean. In Effects of ocean variability on recruitment and an evaluation of parameters used in stock assessment models. Edited by R.J. Beamish and G.A. McFarlane. Can. Spec. Publ. Fish. Aquat. Sci. No. 108. pp. 359-379.

Welch, D.W., Ishida, Y., Nagasawa, K., and Eveson, J.P. 1998. Thermal limits on the ocean distribution of steelhead trout (Oncorhynchus mykiss). North Pac. Anad. Fish. Comm. Bull. 1: 396-404.

Welch, D.W., Ward, B.R., Smith, B.D., and Eveson, J.P. 2000. Temporal and spatial responses of British Columbia steelhead (Oncorhynchus mykiss) populations to ocean climate shifts. Fish. Oceanogr. In press. 